Our Nature (2012) 10: 8-16

\title{
Freshwater Fish Species of the Oorlogskloof River, Northern Cape Province, South Africa
}

\author{
P.P. Ramollo ${ }^{1 *}$, M. Schumann ${ }^{2}$ and W.A.J. Pretorius ${ }^{3}$ \\ ${ }^{1}$ Northern Cape Department of Environment \& Nature Conservation (DENC) \\ Private BagX6102, Kimberley, 8100, South Africa \\ ${ }^{2}$ Northern Cape Department of Environment \& NatureConservation (DENC), Oorlogskloof Nature Reserve \\ P.Box142, Nieuwoudtville 8180, South Africa \\ ${ }^{3}$ Northern Cape, Department of Environment \& Nature Oorlogskloof Nature Reserve \\ P. Box 142 Nieuwoudtville 8180,South Africa \\ *Email: pramollo@ncpg.gov.za
}

\begin{abstract}
The freshwater fish of Oorlogskloof River were sampled in March 2010. The study aimed to determine the distribution and relative abundance of freshwater fish in the Oorlogskloof River. A total of 4643individuals represented by five fish species belonging to two families were sampled. The Barbus anoplus was only sampled in the upper reaches of the Oorlogskloof River gorge while endangered Labeobarbus capensis appeared downstream in the Oorlogskloof River. Barbus serra dominated the fish species in the system. The invasion of Tilapia sparmanni in this system was confirmed during the survey andthe species appeared to be widespread throughout the system. At this stage it does not appear to be posing a serious threat to the endangered fish species. The Oorlogskloof River can be considered as a potential refuge site for the conservation of some endemic and threatened freshwater fishes of South Africa.
\end{abstract}

Key words: Abundance, conservation, distribution, endemic, Oorlogskloof River

\section{Introduction}

The Oorlogskloof River plays a pertinent role as a spawning and nursery site for endemic and endangered fish species. The sound conservation management of the Oorlogskloof River within the 5000 hectare Oorlogskloof Nature Reserve commenced in 1987. The relative inaccessibility of the Oorlogskloof River, where it flows through the Oorlogskloof gorge south of Nieuwoudtville, has prevented habitat destruction and other impacts prevalent along its upper catchment and other tributaries of the Olifants-Doring system. This has ensured that the Oorlogskloof River, within the Oorlogskloof Nature
Reserve, is of unparallel importance in the Olifants-Doring system as a fish sanctuary (Impson, 1995).On the southern side of the Oorlogskloof Nature Reserve, the Oorlogskloof River becomes known as the Kobee River where the Klein Kobee River joins it. The Kobee is a tributary of the Doring River which runs into the Olifants River at Melkboom in the Western Cape Province. The Kobee River probably forms an important link for the clanwilliam yellowfish (Labeobarbus capensis), sawfin (Barbus serra) and clanwilliam sandfish (Labeo seeberi) on their migration from the Doring River to the spawning and nursery 
P.P. Ramollo, M. Schumann and W.A.J. Pretorius / Our Nature (2012) 10: 8-16

grounds in the Oorlogskloof River gorge (Abrahams and Pretorius, 2000).

The Oorlogskloof River has a relatively low diversity of indigenous fish species and is dominated by cyprinids. Abrahams and Pretorius (2000) recorded a total of six fish species in the Oorlogskloof-Kobee River, with two alien species namely the smallmouth bass (Micropterus dolomieu) and bluegill sunfish (Lepomis macrochirus) recorded in the lower reaches of the Oorlogskloof River. A natural barrier of huge boulders is located in the lower reaches of the Oorlogskloof River (south of the Oorlogskloof Nature Reserve) and appears to be preventing these two species from migrating further upstream and reaching the Oorlogskloof Nature Reserve. Both the endangered sawfin (B. serra) and clanwilliam sandfish ( $L$. seeberi) are endemic and spawn successfully within the Oorlogskloof River. The value of the reserve for indigenous fish conservation is further enhanced, as Barbus anoplus also occurs in the Oorlogskloof River system. According to Impson (1995) B. anoplus in the Oorlogskloof Rivermay be a subspecies, as it is genetically distinct from other populations of the Olifants River and Orange-Vaal River system. The clanwilliam yellowfish (L.capensis), classified as vulnerable, has also been recorded in the Oorlogskloof and Kobee rivers. The last time it was recorded in the Oorlogskloof Nature Reserve was in 1982 and the cause for its decline in the reserve is unknown and need further investigation (Abrahams and Pretorius, 2000).

In 2009 reports were received that there were numerous small fish in the Nieuwoudtville municipal dam (pers. comm. Pretorius), which lies within the catchment of the Oorlogskloof River north of the Oorlogskloof Nature Reserve. These were subsequently netted using a seine net and proved to be banded tilapia (Tilapia sparmanni). In March 2010 a survey was conducted in the Oorlogskloof River by a team of officials from the Northern Cape Department of Environment and Nature Conservation and CapeNature. The aim was to investigate the distribution and abundance of the indigenous species known to occur in this river, as well as investigate whether the $T$. sparmannihad invaded the Oorlogskloof River from the Nieuwoudtville municipal dam. The Nieuwoudtville area was flooded in July 2007 making this a distinct possibility.

\section{Materials and methods}

\section{Site description}

The Oorlogskloof River originates in the Roggeveld Mountains near Calvinia in the Northern Cape Province, South Africa. It can be regarded as naturally seasonal, with flows in summer ceasing until the first major rains in the catchment in winter. However, the flow regime is highly variable and unpredictable (Abrahams and Pretorius, 2000). In its upper catchment, it flows through livestock farms and arable fields. Fields are often overgrazed and much of the riparian vegetation is disturbed with alien terrestrial plants such as mesquite (Prosopis glandulosa). An area approximately six kilometres upstream of the northern boundary of Oorlogskloof Nature Reserve has been invaded by mesquite and blue gum (Eucalyptus camaldulensis). The Oorlogskloof Nature Reserve, where most of the survey took place, is situated on the Bokkeveld Plateau in the Nieuwoudtville 
P.P. Ramollo, M. Schumann and W.A.J. Pretorius / Our Nature (2012) 10: 8-16

area and falls within an area marked by sharp climatic, geomorphological and biological transition (Abrahams and Pretorius, 2000). South of Nieuwoudtville the Oorlogskloof River drops into a deep ravine which forms the eastern boundary of Oorlogskloof Nature Reserve. The terrain bordering the river is rocky and almost inaccessible and has prevented habitat destruction and other adverse anthropogenic impacts prevalent along its upper catchment.

\section{Study area}

The same 32 sites sampled in 2000 by Abrahams and Pretorius were sampled again in March 2010. These sites were all located in the Oorlogskloof River gorge above the Klein Kobee River and Oorlogskloof River junction. In addition the Nieuwoudtville municipal dam was also sampled. Fish were collected using a seine net $(6 \mathrm{~m} \times 1 \mathrm{~m})$ at each sampling site. Gill nets were not used due to the high numbers of endemic and endangered fish species in the study area. A subsample of 50 specimens was measured for the standard length and total length and the remaining were counted for total numbers.

\section{Data Analysis}

Fish data collected was analyzed using Shannon-Wiener Index $(\mathrm{H})$ to evaluate species diversity. The index is determined by both the number of species and the even distribution of individuals among those species (relative dominance). It was calculated using the following equation:

$\mathrm{H}=-\mathrm{P}_{\mathrm{i}}\left(\ln \mathrm{P}_{\mathrm{i}}\right)$,

where $P_{i}($ relative abundance $)=n i / N$, ni $=$ the number of individuals within a species,
$\mathrm{N}=$ total number of individuals in all species,

$\ln =$ natural $\log ,=$ sum of the values

for each species. Therefore percentage $\left(\% \mathrm{P}_{\mathrm{i}}\right)=$ the number of individuals within a species (ni) divided by the total number of individuals $(\mathrm{N})$ present in the entire sample $\mathrm{x}$ 100.The relative abundance gave comparisons of diversity at all the sampled sites.

\section{Results}

M. dolomieu and L. macrochirus have previously been recorded in the lower reaches of the Oorlogskloof River, below a natural barrier. This study showed that these alien fish were still not present above the natural barrier. The fish species recorded in the Oorlogskloof river gorge above the natural barriers were namely: B. serra, $B$. anoplus, $L$. seeberi, $L$. capensis and translocated T. sparmanni. Of the indigenous fish caught in the Oorlogskloof River $B$. serra comprised the largest proportion of $80.4 \%(n=3735)$, followed by L. seeberi $8.01 \%(\mathrm{n}=372), B$. anoplus $8.00 \%(\mathrm{n}=371)$, L. capensis $0.60 \%(\mathrm{n}=28)$ and $T$. sparmanni $3.00 \%(\mathrm{n}=137)$ occurred throughout the range sampled with the small species $B$. anoplus largely restricted to the Oorlogskloof River (Tab. 1).

\section{a) B. anoplus}

During this study the indigenous $B$. anoplus was distributed in low numbers and contributed a relative abundance of $8.0 \%$ (Tab. 1). The population appeared to be more abundant in upstream than in downstream. All the sites where it was recorded comprised predominantly of juveniles of 2-4 years of age and ranged in 
P.P. Ramollo, M. Schumann and W.A.J. Pretorius / Our Nature (2012) 10: 8-16

length from $29 \mathrm{~mm}$ to $95 \mathrm{~mm}$. Most individuals were recorded at site $2(n=183)$ and site $3 \quad(\mathrm{n}=110) \quad($ Tab. 1). Most individuals appeared to be embedded with digenean cysts.

\section{b) L. seeberi}

During this study L. seeberi(endangered) was found to be substantially distributed in the Oorlogskloof River system. It contributed a relative abundance of $8.01 \%$ (Tab. 1). Total length ranged from $22 \mathrm{~mm}$ to $270 \mathrm{~mm}$ with a good distribution of juveniles, sub-adults and adults.

\section{c) B. serra}

The endangered $B$. serra was the most abundant species in the system and it exceptionally comprised of $80.4 \%$ of the total catch (Tab. 1). The bigger the pools the more fish were recorded during this study. Its populations were dominated by juvenile fish and subadults. It's standard-lengths varied between $16 \mathrm{~mm}$ and $270 \mathrm{~mm}$.

\section{d) L. capensis}

The numbers of endemic L. capensis were relatively low, contributing to a relative abundance of $0.60 \%$ (Tab. 1). They were recorded at only six of the sampled sites. Total length ranged from $75 \mathrm{~mm}$ to $125 \mathrm{~mm}$. Its populations were dominated by sub adults fish.

\section{e) T. sparmanni}

During this study $T$. sparmanni comprised $3.00 \%$ of total catch (Tab. 1).It appeared remarkably widespread in the system with site 14 comprising the highest recorded number of $(\mathrm{n}=45)$.Most of the T. sparmanni juveniles at the sampled sites were between $30 \mathrm{~mm}$ and $80 \mathrm{~mm}$, but sub adults of up to
$145 \mathrm{~mm}$ were also present. Very small juveniles ranging from $30 \mathrm{~mm}$ were found more frequently at other sites.

\section{Discussion}

Generally in aquatic ecosystem there are factors that affect fish species composition, distribution and abundance. The variation in individual growth in fish populations occur because growth is strongly dependent on food availability, flow dynamics and water temperature (Persson and De Roos, 2001; DeAngelis Roseet al., 1993; Cincotta and Staffeur, 1984). However in natural populations there is a trend of species size dissimilarity amongst individuals born at the same time in the same environment, affected and influenced by biotic and abiotic factors (Persson and De Roos, 2001; Husset al., 2007). Depending on size reached at certain times of the season, variability in life history among individuals can be crucial for whether a total recruitment failure will take place or whether some larger individuals can survive (Huss et al., 2007). When favourable conditions are attained, the survival improves and the dominant group begins to grow.

During this survey, only a hand drawn seine net was used to sample the fish populations. This net may have been biased in that only fairly shallow pools, or shallow areas in large pools, could be netted and therefore larger individuals may be absent from the sample. However, despite a possible bias towards smaller size, the fish results manifested that the Oorlogskloof River contains healthy endemic fish populations with juveniles of sawfin and sandfish in particular, occurring in multiple pools netted. The Oorlogskloof-Kobee Rivers also provide connectivity for the 
P.P. Ramollo, M. Schumann and W.A.J. Pretorius / Our Nature (2012) 10: 8-16

Table 1. Species composition recorded during the sampling surveys 2010

\begin{tabular}{|c|c|c|c|c|c|c|}
\hline Locality & B. anoplus & B. serra & $\begin{array}{l}\text { L. } \\
\text { capensis }\end{array}$ & L. seeberi & $\begin{array}{l}T . \\
\text { sparmanni }\end{array}$ & Total \\
\hline Site A1 & 4 & 17 & & 20 & & 41 \\
\hline Site 1 & 53 & 49 & & 4 & & 106 \\
\hline Site 2 & 183 & 27 & & 75 & 3 & 288 \\
\hline Site 3 & 110 & 15 & & 83 & & 208 \\
\hline Site 4 & 4 & 18 & & 3 & & 25 \\
\hline Site 5 & 7 & 50 & & & 3 & 60 \\
\hline Site 6 & & 141 & & 1 & 9 & 151 \\
\hline \multicolumn{7}{|l|}{ Site 7} \\
\hline Site 8 & & 442 & & 33 & 1 & 476 \\
\hline Site 9 & & & & & 11 & 11 \\
\hline Site 10 & & & & 1 & & 1 \\
\hline Site 11 & & & & 1 & & 1 \\
\hline Site 12 & & 120 & & & 5 & 125 \\
\hline Site 13 & & 58 & & 2 & 1 & 61 \\
\hline Site 14 & & 2 & & 1 & 45 & 48 \\
\hline Site 15 & 5 & 402 & & 23 & 2 & 432 \\
\hline Site 16 & & 120 & 1 & 12 & & 133 \\
\hline Site 17 & & 72 & & 24 & & 96 \\
\hline Site 18 & 5 & 88 & & 14 & 5 & 112 \\
\hline Site 19 & & 63 & & 3 & & 66 \\
\hline Site 20 & & 49 & & 3 & 3 & 55 \\
\hline Site 21 & & 46 & & 6 & & 52 \\
\hline Site 22 & & 80 & & 1 & & 81 \\
\hline Site 23 & & 219 & & 6 & & 225 \\
\hline Site 24 & & 20 & 1 & 1 & 9 & 31 \\
\hline Site 25 & & 181 & & 3 & 5 & 189 \\
\hline Site 26 & & 124 & 14 & 7 & 3 & 148 \\
\hline Site 27 & & 51 & 8 & 26 & 11 & 96 \\
\hline Site 28 & & 353 & & 3 & 1 & 357 \\
\hline Site 29 & & 40 & & 2 & & 42 \\
\hline Site 30 & & 49 & 3 & & & 52 \\
\hline Site 31 & & 687 & 1 & 11 & 5 & 704 \\
\hline Site 32 & & 152 & & 3 & 15 & 170 \\
\hline Total & 371 & 3735 & 28 & 372 & 137 & 4643 \\
\hline$\% p i$ & $8.00 \%$ & $80.4 \%$ & $0.60 \%$ & $8.01 \%$ & $3.00 \%$ & $100 \%$ \\
\hline
\end{tabular}


upstream migration of these fish and the dispersal of sub adult fish from their nursery grounds to the main stem Doring River (Impson, 1997).

\section{a) B. anoplus}

This species prefers cold waters and occurs in a wide range of habitats varying from shallow streams to the shorelines of large impoundments (Cambray et al., 1978; Skelton, 2001). It breeds in the summer when rivers are filledwith water. It is omnivorous and is preyed upon by larger fish and birds. Unlike other fish species that migrates upstream in order to spawn, spawning migration of $B$. anoplusis not necessary because they can spawn locally if there is an increase in the water flows and inundation of the marginal vegetation (Cambray et al., 1978).

During this study the indigenous $B$. anoplus was distributed in low numbers and contributed a relative abundance of $8.00 \%$ (Tab. 1). The high numbers of B. anoplus occurring upstream in the Oorlogskloof Nature Reserve can probably be attributed to bigger size of the pools with associated diversity of marginal vegetation. The number of juveniles versus adults could be due to a bias in the seine netting, with adults possibly preferring the deeper vegetated areas of the pools. According to Cambray and Bruton (1985), size of $73 \mathrm{~mm}$ fork length females reflects age of 3-4 and size $60 \mathrm{~mm}$ of males reflects 2-3 years. Most of the individuals recorded during this study appeared to be within the aforementioned range. B. anoplus can survive harsh environmental conditions but if the area is affected by climate change many individuals may die as the shallow, deep and remnant pools dry out.

\section{b) L. seeberi}

L. seeberi prefers pool waters and deep runs of the river (Skelton, 2001).It is distributed in the Olifants-Doring river system but seems to be absent in the Upper Olifants river. The invasive alien fish species such as $M$. dolomieu, $M$. salmoides, and $L$. macrochirus coupled with agricultural activities have made a significant population decline of L.seeberi (Impson 1997). The results of this study concurred with the study conducted by Abrahams and Pretorius (2000) who reported high numbers at most of the sampled sites. The abundance of $L$. seeberi in the river can probably be attributed to successful spawning due to intact habitat, and the lack of the more aggressive predatory alien fish, as well as the presence of unlimited food availability from the decomposed vegetation. This in turn encourages the rapid increase of freshwater invertebrates, a diet for several other fish species. Results of fish measurements showed that the Oorlogskloof river populations have a good distribution of juveniles, sub-adults and adults. What was encouraging was that juveniles with $<50 \mathrm{~mm}$ total length occurred at the sites occupied by the translocated species $T$. sparmanni. Indications are therefore that the $T$. sparmanni may not pose a threat to abundance and distribution of $L$. seeberiat this stage. According to Skelton (2001) the decline in the recruitment of $L$. seeberi is caused by poor water quality, habitat modification and dam construction which cause significant changes in the annual flow 
P.P. Ramollo, M. Schumann and W.A.J. Pretorius / Our Nature (2012) 10: 8-16

patterns. The damming of the Oorlogskloof River and habitat destruction should be discouraged in order to ensure the conservation of this species. Climate change predictions should also be taken into account during any conservation planning, as an increase in extreme events such as droughts, could cause a crowding effect on fish resulting in massive fish kills due to lack of oxygen. Due to the relative abundance of $L$. seeberi and good age distributions recorded, this population is of huge importance and due to its conservation status; it should be monitored regularly to determine population decrease.

\section{c) B. serra}

This fish favours deep pools(Skelton, 2001).It used to be widespread and substantially abundant in the Olifants River but the number have decline due to invasive alien fish and habitat degradation and fragmentation (Impson, 1999).In late spring and summer the school of adults migrate upstream to shallow riffles and cobbles to spawn (Kinget al., 1998; Skelton, 2001). According to Paxtonet al. (2002) the Oorlogskloof-Kobee River system is the most important in terms of $B$. serra habitat and recruiting populations are known to occur in the Oorlogskloof Nature Reserve. The high numbers and good age distribution of $B$. serra recorded during this survey indicateda healthy population status and that there is still significant recruitment of this species in the system. Relatively high numbers of fish were collected and showed distinct cohorts and thus supported the findings of Abrahams and Pretorius (2000)and Paxton et al.(2002).The size variations showed that the predation by $T$. sparmanni is low and therefore not affecting the distribution and abundance of fish at this juncture. The increase in the numbers of $B$. serra at some of the sites may have been the result of a variety of substrate, appearance of submerged vegetation and woody debris which are an important refuge for small fish. Another factor may have been changes in the water velocity and depth at certain sites, which favours the establishment of these species.

\section{d) L. capensis}

L. capensis is endemic to the OlifantsDoring River system and it prefers deep pool waters (Skelton, 2001). It is widespread in the Doring River but the numbers appear to be declining due to bass invasion/predation (Paxton et al., 2002). The numbers recorded during this study supported previous findings of Abrahams and Pretorius (2001) which recorded low numbers of fish. Results showed a poor reproductive success or perhaps high mortality of juveniles, which likely will lead to long-term population decline.

Causes for the poor success of $L$. capensis in this system could possibly be ascribed to environmental flows, habitat integrity and competition of food or perhaps invasion by $T$. sparmanni. The mature individuals of $L$. capensis migrate upstream to spawn in summer in response to the increased water flows (King et al., 1998; Skelton, 2001).There are indications that they might not spawn every year due to environmental factors, which may be why juvenile fish numbers were so low. However, L. capensis is a multiple spawner during the breeding season (Cambray, 1999), so if there were spawning events 
P.P. Ramollo, M. Schumann and W.A.J. Pretorius / Our Nature (2012) 10: 8-16

over the last few years, more sub adults and juveniles should have been recorded. The bias of the seine net also needs to be taken into account, but as healthy numbers of juvenile and sub adults of the other fish sampled were recorded, one would have expected a fairly good representation of juvenile and sub adult numbers of $L$. capensis as well.

\section{e) T. sparmanni}

T. sparmanni is tolerant of a wide range of habitats, preferring slow moving or standing waters with submerged or emergent vegetation (Skelton, 2001). It is omnivorous and feeds on algae, soft plants, small invertebrates such as insects and small fish (Skelton, 2001).It presence in the system is likely attributed to the flooding of Municipal dam in 2007. Individuals were also netted in this dam during this study and in 2009 (pers. comm. Pretorius). It was considered common along the entire length of the Oorlogskloof River gorge surveyed, but were more abundant downstream than upstream probably due to habitat requirements. According to Skelton (2001) it attains a standard length of about $230 \mathrm{~mm}$ but none were recorded, perhaps due to seine net bias or due to habitat limitations. Large numbers of juvenile and sub adult $T$. sparmanni were recorded indicating successful recruitment in the system, further signifying its distribution in the system.

\section{Conclusion}

The Oorlogskloof River has a relatively low diversity of indigenous fish species and is dominated by cyprinids. This survey reaffirmed the importance of the Oorlogskloof Nature Reserve as an important breeding and nursery area for endangered $L$. seeberi, $B$. serra and B. anoplus, despite the invasion of $T$. sparmanni. The Oorlogskloof River supports a healthy fish species composition and provides good breeding and nursery ground for endangered fish species. It is one of a few potential statutory conservation areas and a natural riverine sanctuary on the Olifants-Doring River system. Accordingly it is of immense importance to the survival of at least two (possibly three, including $L$. capensis) threatened fish species and the genetically-unique $B$. anoplus. $L$. seeberi was widespread throughout in the system while $B$. serra was the most dominant species. Interestingly no $B$. anoplus were recorded at the sites where $L$. capensis were recorded and this apparent association needs further investigation, as well as why $L$. capensis does not appear to be recruiting or surviving well in this system. Regular monitoring and more research are urgently required in the Oorlogskloof Kobee river system in order to ensure the conservation of these important fish species and their habitat.

\section{Acknowledgements}

We would like to thank the Oorlogskloof Nature Reserve field rangers,Mr Johannes Afrika, Mr Leon Koopman, $\mathrm{Mr}$ Esau Andrews, Mr Nathan Kotze and Mr Koos Koopman, Ms Wilma Smith (Oorlogskloof Nature Reserve intern), as well as the volunteers from the Nieuwoudtville community who assistedwith the survey; CapeNature officials, in particular Mr Dean Impson,Dr Martine Jordaanand Ms Jean Gouws for assisting with the survey and ongoing support, DENC supervisors Ms Elsabe Swart and Mr Julius Koen for creative inputs provided and for editing the 
P.P. Ramollo, M. Schumann and W.A.J. Pretorius / Our Nature (2012) 10: 8-16

document and Department of Environment and Nature Conservation for financial support and use of equipments. Special thanks to Dr Bruce Paxton of University of Cape Town, Freshwater Consulting for guidance in writing this manuscript.

\section{References}

Abrahams, A.A.M. and W.A.J. Pretorius. 2000. The freshwater fish fauna of Oorlogskloof Nature Reserve, Northern Cape, South Africa. Unpublished Report. Northern Cape Nature Conservation Service, Kimberley.

Cambray, J.A., S., Hahndiek and Q. Hahndiek 1978. The juvenile fish population in the marginal areas of the Hendrik Verwoerd Dam.J.Limnol.Soc.S.Afr.44(1): 21-30.

Cambray, J.A. and M.N. Bruton. 1985. Age and growth of a colonizing minnow, Barbusanoplus, in a man-made lake in South Africa. Environ. Biol. Fishes12(2): 131-141.

Cambray, J.A. 1999. Threatened Fishes of the world: Barbus capensis A. Smith, 1841 (Cyprinidae).Environ. Biol. Fishes54: 150.

Cincotta, D.A. and J.R Staffeur. 1984. Temperature preference and avoidance studies of six North American freshwater species.Hydrobiol.109:173 -177.

DeAngelis, D.L., K.A., Rose, L. B., Crowder,E. A., Marschall and D. Lika 1993. Fish Cohorts Dynamics. Application of Complimentary Modelling approaches.The Am. Nat. 140 (4): 604622.

De Roos, A.M. and L. Persson.2001. Physiologically structured models-from versatile technique to ecological theory.Oikos94: 51-71.

Huss, M., P., Bystrom and L. Persson 2007. The origin and development of individual size variation in early pelagic stages of fish.Oecol.153(1):57-67.

Impson, N.D. 1995. Distribution of fishes in the Oorlogskloof and Kobee Rivers. Unpublished Report. Cape Nature Conservation, Jonkershoek.

Impson, N.D. 1997. Threatened fishes of the world: Labeo seeberi Gilchrist \& Thompson, 1911(Cyprinidae).Environ. Biol. Fishes 49 (4): 480.

Impson, N.D. 1999. Threatened fishes of the world: Barbus serra Peters, (Cyprinidae).Environ. Biol. Fishes 54: 44.

King, J.M., J.A., Cambray and D.Impson 1998. Linked effects of dam-released floods and water temperatures on spawning of the Clanwilliam yellowfish Barbus capensis.Hydrobiol.384: 245265.

Paxton, B.R., B.M., Clarke and C.A. Brown 2002. An assessment of the effects of habitat degradation and exotic fish species invasions on the distribution of three endemic cyprinids: Barbus capensis, Barbus serra and Labeo seeberi in the Olifants and Doring Rivers, Western Cape. Department of Water Affairs and Forestry, Report No. PB E000-00-1302.

Persson, L. and A.M. De Roos. 2006. Food-dependent individual growth and population dynamics in fishes.J. Fish Biol.69 (3): 1-20.

Skelton, P.H. 2001. A complete guide to the freshwater fishes of southern Africa. Southern Book Publishers, Halfway House. pp. 117-291. 